\title{
MANUSIA DAN AGAMA
}

\author{
Achmad Asrori \\ Universitas Islam Negeri (UIN)Raden Intan Lampung \\ Email: achmadasrori@gmail.com
}

\begin{abstract}
The study of humans is a very interesting study, because besides being approachable from various aspects, it also concerns us as human beings. This study of humans has been done for a long time since the time of the ancient philosophers in Greece. They have started talking about humans, besides talking about God and the universe. This study of humans also eventually gave birth to various scientific disciplines, such as sociology, anthropology, biology, psychology, and other sciences.Religion is a part that cannot be separated from humans, considering that since humans were born into the world, God has actually been equipped with religion. For this reason, the relationship between humans and religion will be explained in this section so that it becomes clear that religion is an absolute necessity for humans and humans cannot live in order and prosperity in this world without religion. In other words, human nature is religious, so when a human claims to be non-religious means he has lied to himself and at the same time has done wrong against him.
\end{abstract}

Keywords: Humans and Religion.

\begin{abstract}
Abstrak
Kajian tentang manusia merupakan kajian yang sangat menarik, karena selain dapat didekati dari berbagai aspek, juga menyangkut kita sebagai manusia. Studi tentang manusia ini telah dilakukan sejak lama sejak zaman para filsuf kuno di Yunani. Mereka sudah mulai berbicara tentang manusia, selain berbicara tentang Tuhan dan alam semesta. Kajian terhadap manusia ini juga akhirnya melahirkan berbagai disiplin ilmu, seperti sosiologi, antropologi, biologi, psikologi, dan ilmu lainnya. sebenarnya telah dilengkapi dengan agama. Untuk itu hubungan antara manusia dan agama akan dijelaskan pada bagian ini sehingga menjadi jelas bahwa agama merupakan kebutuhan yang mutlak bagi manusia dan manusia tidak dapat hidup tertib dan sejahtera di dunia ini tanpa agama. Dengan kata lain, fitrah manusia adalah religius, sehingga ketika manusia mengaku nonreligius berarti ia telah berbohong kepada dirinya sendiri dan pada saat yang sama telah berbuat salah terhadapnya.
\end{abstract}

Kata Kunci: Manusia dan Agama.

\section{A. Pendahuluan}

Mengkaji manusia berdasarkan ayat-ayat Alquran menjadi sangat penting, terutama bagi umat Islam, mengingat begitu banyaknyakajian tentang manusia dengan pendekatan lain. Kajian ini untuk memberikan informasi yang jelas dan benar dan tidak menyimpang dari ketentuan-ketentuanyang sudah digariskan oleh Alquran yang diakui sebagai sumber kebenaran yanghakiki.

Pada bagian ini juga akan dikaji permasalah lain yang sangat terkaitdengan permasalahan manusia, yakni permasalahan agama. Agama merupakansuatu bagian yang tidak dapat dilepaskan dari manusia, mengingat sejak manusialahir ke dunia sebenarnya sudah dibekali oleh Allah dengan agama. Karena itulah, 
keterkaitan antara manusia dan agama akan dijelaskanpada bagian ini sehingga menjadi jelas bahwa agama merupakan kebutuhan mutlak bagi manusia dan manusia tidak dapat hidup dengan teratur dan sejahteradi dunia ini tanpa agama. Dengan kata lain, fitrah manusia adalah beragama,sehingga ketika manusia mengaku tidak beragama berarti ia telah membohongidirinya dan sekaligus telah berbuat zhalim terhadap dirinya.

Kajian ini akan mengurai bagaimana konsep manusia menurut pandanganIslam, khususnya berdasarkan Alquran. Di samping itu, kajian ini juga akanmenganalisis keterkaitan antara manusia dengan agama dan sejauh manakahmanusia membutuhkan agama dalam hidup dan kehidupannya sebagai bekaldalam kehidupan nantinya di akhirat.

\section{B. Pembahasan}

\section{Pandangan Umum Tentang Manusia}

Manusia merupakan satu bagian dari alam semesta yang bersama-sama dengan makhluk hidup lainnya mengisi kehidupan di alam semesta ini. Dibandingkan dengan binatang, manusia memiliki fungsi tubuh dan fisiologis yang tidak berbeda. Namun, dalam hal yang lain manusia tidak dapat disamakan dengan binatang, terutama dengan kelebihan yang dimilikinya, yakni akal, yang tidak dimiliki oleh binatang.

Para ahli ilmu pengetahuan tidak memiliki kesamaan pendapat mengenai manusia. Perbedaan pendapat ini disebabkan oleh adanya kekuatan dan peran multidimensional yang diperankan oleh manusia. Mereka melihat manusia hanya dari satu aspek saja, padahal aspek yang ada cukup banyak. Karena itulah hasil pengamatan mereka tentang manusia berbeda-beda antar satu dengan lainnya. Perbedaan aspek ini pula yang kemudian melahirkan berbagai disiplin ilmu yangterkait dengan manusia.

\section{Manusia dalam Pandangan Alquran}

Untuk melihat pandangan Alquran mengenai manusia, di bawah ini akan diuraikan satu persatu mengenai kata yang digunakan Alquran untuk menyebut manusia, asal kejadian manusia, potensi manusia, fungsi manusia, dan jati diri manusia.

\section{a. Sebutan Alquran untuk Manusia}

Penekanan kata insan ini adalah lebih mengacu pada peningkatan manusia ke derajat yang dapat memberinya potensi dan kemampuan untuk memangku jabatan khalifah dan memikul tanggung jawab dan amanat manusia di muka bumi, karena sebagai khalifah manusia dibekali dengan berbagai potensi seperti ilmu, persepsi, akal, dan nurani. Dengan potensi-potensi ini manusia siap dan mampu menghadapi segala permasalahan sekaligus mengantisipasinya. Di samping itu, manusia juga 
dapat mengaktualisasikan dirinya sebagai makhluk yang mulia dan memiliki kedudukan yang lebih tinggi dari makhluk lain dengan berbekal potensi-potensi tadi. ${ }^{1}$

Penyebutan manusia dengan nas lebih menonjolkan bahwa manusia merupakan makhluk sosial yang tidak dapat hidup tanpa bantuan dan bersama-sama manusia lainnya. Al-Quran menginformasikan bahwa penciptaan manusia menjadi berbagai suku dan bangsa bertujuan untuk bergaul dan berhubungan antar sesamanya (ta'aruf), saling membantu dalam melaksanakan kebajikan, saling menasihati agar selalu dalam kebenaran dan kesabaran, dan menanamkan kesadaran bahwa kebahagiaan manusia hanya mungkin terwujud bila mereka mampu membina hubungan antar sesamanya.

Menurut al-Raghib al-Ashfahani, manusia disebut basyar karena manusiamemiliki kulit yang permukaannya ditumbuhi rambut dan berbeda dengan kulithewan yang ditumbuhi bulu. Kata ini dalam al-Quran digunakan dalam makna yang khusus untuk menggambarkan sosok tubuh lahiriah manusia.

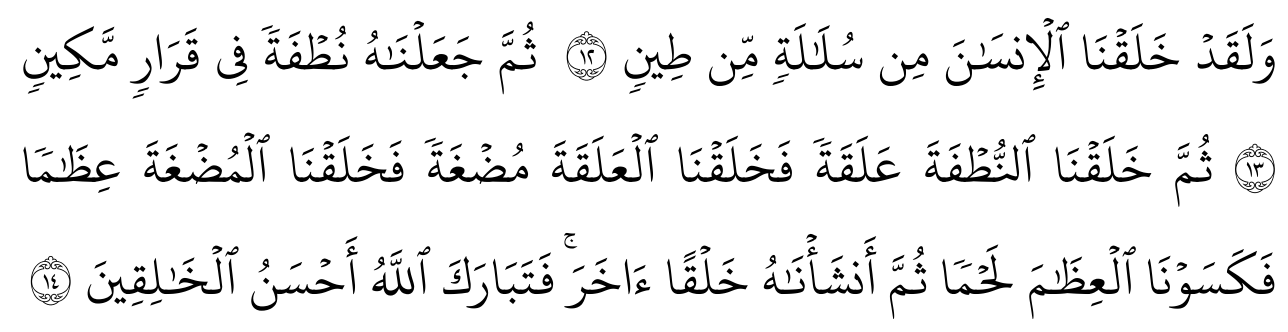

Artinya: Dan Sesungguhnya Kami telah menciptakan manusia dari suatu saripati (berasal) dari tanah. Kemudian Kami jadikan saripati itu air mani (yang disimpan) dalam tempat yang kokoh (rahim). Kemudian air mani itu Kami jadikan segumpal darah, lalu segumpal darah itu Kami jadikan segumpal daging, dan segumpal daging itu Kami jadikan tulang belulang, lalu tulang belulang itu Kami bungkus dengan daging. kemudian Kami jadikan Dia makhluk yang (berbentuk) lain. Maka Maha sucilah Allah, Pencipta yang paling baik. QS Al-Mu'minuun: 12-14)

Karena itulah Nabi Muhammad saw diperintahkan untuk menyampaikan bahwa beliau sama seperti manusia lainnya, yang membedakannya hanyalah beliau diberi wahyu.

\section{b. Asal Kejadian Manusia}

Al-Quran tidak membicarakan proses kejadian manusia secara detail, sebagaimana yang dijelaskan oleh ilmu biologi atau ilmu kedokteran. Namun demikian, al-Quran memberikan isyarat mengenai asal kejadian manusia yang tidak bertentangan dengan ilmu pengetahuan,

1 Aflatun Mukhtar, Tunduk kepada Allah: Fungsi dan Peran Agama dalam Kehidupan Manusia, (Jakarta: Paramadina, 2001), h. 102. 
khususnya biologi. Mengenai asal kejadian manusia ini, al-Quran menjelaskan melalui beberapa ayatnya yang dapat dijelaskan sebagai berikut.

Pertama, Al-Quran menegaskan bahwa manusia pertama adalah Adam a.s. Allah menciptakan Adam a.s. melalui proses yang unik dan berbeda dengan manusia-manusia lainnya. Allah dengan sifat Maha Kuasa-Nya menciptakan Adam dari tanah (turab) dan hanya dengan firman-Nya: "kun fayakun" yang berarti jadilah, maka jadilah ia. Allah Swt berfirman Q.S. Ali-Imran ayat 59.

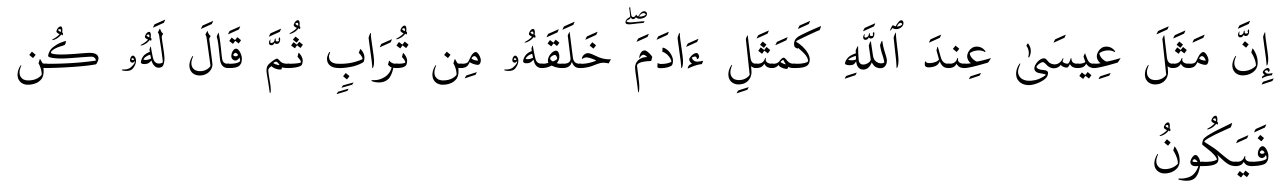

Artinya: Sesungguhnya misal (penciptaan) Isa di sisi Allah, adalah seperti (penciptaan) Adam. Allah menciptakan Adam dari tanah, kemudian Allah berfirman kepadanya: "Jadilah" (seorang manusia), Maka jadilah Dia.

Kedua, panusia yang lain (selain Adam atau keturunan Adam) diciptakan oleh Allah dari saripati tanah, yang berproses menjadi sperma (nuthfah), segumpal darah ('alaqah), segumpal daging (mudghah), tulang belulang ('izham), hingga menjadi janin (khalqan akhar).

Ketiga, proses manusia selanjutnya dijelaskan, mulai dalam kandungan manusia dibekali ruh kemudian potensi pendengaran, penglihatan, dan hati. Dalam al- Setelah sempurna proses kejadiannya kemudian Allah mengeluarkannya menjadi bayi, tumbuh menjadi dewasa, hingga dimatikan Allah.

\section{c. Potensi Manusia}

Dalam al-Quran dijelaskan bahwa Allah membekali manusia dengan dua potensi pokok, yakni:

\section{1) Potensi kecerdasan (IQ)}

Al-Quran mengisyaratkan hal ini dengan menjelaskan proses pengajaran yang diberikan oleh Allah kepada Adam, yang dalam waktu singkat dapat menguasai semua nama yang ada di surga. Hal tersebut mengindikasikan bahwa Adam, sebagai manusia pertama, memiliki kecerdasan yang lebih dibandingkan malaikat yang ternyata tidak mampu menyebutkan semua nama yang ada di surga.

\section{2) Potensi Tauhid (Agama)}

Hal ini diisyaratkan oleh al-Quran dengan persaksian yang diberikan oleh Allah kepada jiwa (ruh) yang ada pada setiap calon bayi yang masih dalam kandungan sang ibu. Semua jiwa itu mempersaksikan bahwa Allah sebagai Tuhannya. 


\section{d. Fungsi Manusia}

Di bumi inilah manusia dapat berperan sesuai dengan bidangnya masing-masing. Peran apa saja yang dimainkan manusia di bumi ini, alQuran menggariskan jangan sampai manusia keluar dari dua fungsi pokoknya, yakni: Pertama, fungsi kekhalifahan (khalifah Allah). Kehadiran manusia di bumi ini adalah sebagai khalifah atau wakil Allah di bumi. Khalifah bisa juga diartikan sebagai pemimpin. Karena itu, manusia harus dapat memerankan dirinya sebagai pemimpin di muka bumi ini. Fungsi kepemimpinan ini harus diperankan manusia sesuai dengan kapasitasnya masing-masing yang banyak didukung oleh potensi kecerdasannya.

Kedua, fungsi ibadah (hamba Allah). Di samping manusia harus menjadi khalifah di bumi, manusia juga harus melakukan fungsi utamanya, yakni beribadah kepada Allah. Fungsi ibadah ini dapat dijalankan manusia sesuai dengan petunjuk-petunjuk yang diberikan oleh Allah melalui al-Quran dan juga yang dijelaskan oleh Nabi melalui hadisnya. Fungsi ini sangat didukung oleh potensi agama yang dimiliki manusia. Semakin tinggi potensi keagamaan manusia, maka akan semakin maksimal dia dapat beribadah kepada Allah.

Dua fungsi di atas harus berjalan bersama-sama dan tidak boleh manusia hanya menjalankan satu fungsi saja serta meninggalkan fungsi yang lain. Sebagai teladan manusia, Nabi Muhammad saw. menyontohkan bagaimana melakukan kedua fungsi itu dalam kehidupan beliau, baik sebagai kepala negara maupun sebagai nabi, yang dua-duanya dijalankan dengan sebaik mungkin. Sebagai umatnya kita pun harus meneladaninya dengan berusaha memaksimalkan kedua fungsi itu dalam kehidupan kita.

\section{Pengertian Agama}

Secara etimologis kata 'agama' berasal dari bahasa Sangskerta, yakni $a$ dan gama. A berarti tidak dan gama berarti kocar-kacir atau berantakan. Jadiagama berarti tidak berantakan atau teratur. Dengan makna ini, dapat dipahamibahwa agama memberikan serangkaian aturan kepada para penganutnya sehinggahidupnya tidak berantakan. Agama menyampaikan para pemeluknya kepada suatucara hidup yang teratur. ${ }^{2}$

Dari makna etimologis ini, agama dapat didefinisikan sebagai seperangkat aturan atau ketentuan hidup yang melekat dalam diri manusia agar hidupnya teratur yang merupakan cara menuju suatu kehidupan yang selamat. Yang harus juga ditegaskan di sini adalah bahwa aturan dalam agama ini harus bersumber dari sesuatu yang dipandang melebihi kekuasaan manusia, yakni Tuhan atau yang dianggap seperti Tuhan.

2 Anshary, Endang Saefuddin, Islam, Filsafat dan Agama, (Surabaya: Bina Ilmu, 1979), h. 114. 
Ada pendapat lain yang mengatakan bahwa kata religion berasal dari kata kerja dalam bahasa Latin religere yang menunjukkan arti ibadah yang berasaskan pada ketundukan, rasa takut, dan rasa hormat. Namun, gambaran keagamaan seperti ini hanya bisa dipakai dalam mengartikan agama Samawi. ${ }^{3}$

Dalam bahasa Arab agama dikenal dengan sebutan 'din' dan 'millah'. Kedua istilah ini bisa ditemukan dalam al-Qur'an maupun Sunnah Nabi. Penggunaan istilah 'din' lebih populer daripada 'millah'. Kata 'din' sendiri dalam bahasa Arab berasal dari kata 'dana' yang sebenarnya memiliki beberapa arti, di antaranya cara atau adat istiadat, peraturan, undang-undang, taat atau patuh, pembalasan, menunggalkan ketuhanan, perhitungan, hari kiamat, nasihat, dan agama Din juga bisa berarti aqidah, syari'ah, dan millah. ${ }^{4}$ Dari makna-makna tersebut, maka sebenarnya kata din-lah yang paling tepat untuk menyebut agama Islam, sehingga menjadi Din al-Islam.

Sementara itu, Harun Nasution mengidentifikasi beberapa definisi tentang agama dari para ahli. Agama didefinisikan sebagai berikut:

a. Pengakuan terhadap adanya hubungan manusia dengan kekuatan gaib yang harus dipatuhi.

b. Pengakuan terhadap adanya kekuatan gaib yang menguasai manusia.

c. Mengikatkan diri pada suatu bentuk hidup yang mengandung pengakuan pada suatu sumber yang berada di luar diri manusia dan yang mempengaruhi perbuatan-perbuatan manusia.

d. Kepercayaan pada suatu kekuatan gaib yang menimbulkan cara hidup tertentu.

e. Suatu sistem tingkah laku (code of conduct) yang berasal dari suatu kekuatan gaib.

f. Pengakuan terhadap adanya kewajiban-kewajiban yang diyakini bersumber pada suatu kekuatan gaib.

g. Pemujaan terhadap kekuatan gaib yang timbul dari perasaan lemah dan perasaan takut terhadap kekuatan misterius yang terdapat dalam alam sekitar manusia.

h. Ajaran-ajaran yang diwahyukan Tuhan kepada manusia melalui seorang Rasul. ${ }^{5}$

\section{Unsur Pokok Agama}

Dengan mendasarkan pada berbagai definisi tentang agama, Harun Nasution menegaskan bahwa unsur-unsur pokok yang ada dalam agama adalah:

a. Kekuatan gaib. Dengan adanya kekuatan gaib ini manusia merasa dirinya lemah dan berhajat kepadanya sebagai tempat minta tolong. Karena itu,

\footnotetext{
3 Dadang Kahmad, Sosiologi Agama, (Bandung: Remaja Rosdakarya, 2009), h. 16.

4 Aflatun Mukhtar, Tunduk kepada Allah...,h. 17.

5 Nasution, Harun, Islam Ditinjau dari Berbagai Aspeknya, (Jakarta: UI Press. 1985), h. 10.
} 
manusia merasa harus mengadakan hubungan baik dengan kekuatan gaib tersebut.

b. Keyakinan manusia bahwa kesejahteraannya di dunia ini dan hidupnya di akhirat tergantung pada adanya hubungan baik dengan kekuatan gaib yang dimaksud. Dengan hilangnya hubungan baik itu, kesejahteraan dan kebahagiaannya yang dicari juga akan hilang.

c. Respons yang bersifat emosional dari manusia. Respons itu bisa mengambil bentuk perasaan takut, seperti yang terdapat dalam agamaagama primitif, atau perasaan cinta, seperti yang terdapat dalam agamaagama monoteisme.

d. Paham adanya yang kudus (sacred) dan suci, dalam bentuk kekuatan gaib, dalam bentuk kitab yang mengandung ajaran-ajaran agama bersangkutan dan dalam bentuk tempat-tempat tertentu.

Berdasar pada fenomena-fenomena keagamaan dan kebudayaan yang ada di tengah-tengah masyarakat dan juga dalam kajian antropologi dapat ditemukan adanya lima unsur atau komponen pokok dalam agama, yaitu:

a. Emosi keagaman (religious emotion/getaran jiwa) yang menyebabkan bahwa manusia didorong untuk berperilaku keagamaan.

b. Sistem kepercayaan atau bayangan-bayangan manusia tentang dunia, alam, alam gaib, hidup, mati, dan sebagainya. Sistem kepercayaan ini dalam Islam dikenal dengan aqidah atau iman.

c. Sistem ritus dan upacara keagamaan terwujud dalam aktivitas dan tindakan manusia dalam melaksanakan pengabdian dan kebaktiannya kepada Tuhan dan dalam usahanya untuk berkomunikasi dengan-Nya. Dalam Islam sistem ritus ini dikenal dengan ibadah dan muamalah

d. Kelompok keagamaan atau kesatuan-kesatuan sosial yang mengkonsepsikan dan mengaktifkan agama berikut upacaya-upacara keagamaannya. Kelompok inilah yang biasa disebut pemeluk agama atau umat beragama.

e. Alat-alat fisik yang digunakan dalam ritus dan upacara keagamaan yang berujud tempat-tempat ibadah dan sarana prasarana untuk melakukan aktivitas keagamaan. ${ }^{6}$

\section{Keterkaitan Manusia dengan Agama}

Untuk melihat keterkaitan antara manusia dengan agama, dapat ditelusuri dari beberapa hal, di antaranya kodrat manusia beragama, gambaran manusia beragama, dan kebutuhan manusia akan agama.

${ }^{6}$ Koentjaraningrat, Pengantar Antropologi, (Jakarta: Rineka Cipta, 2002), h. 47-50. 


\section{a. Kodrat Manusia Beragama}

Untuk mengetahui kodrat manusia beragama ini dapat dilihat padabeberapa fenomena berikut:

\section{1) Tentang Doa Keselamatan.}

Setiap orang pasti ingin mendapatkan keselamatan. Ia merasa dirinya selalu terancam. Makin serius ancamannya, doanya akan makin serius pula. Ia merasa kecil hidup di jagat raya ini seperti perahu kecil yang terapung di samudra yang amat luas. Karena ancaman tersebut ia ingin berpegangan dan menyandarkan diri kepada sesuatu yang ia anggap sebagai yang Maha Ghaib dan Maha Kuasa.

\section{2) Tentang Kebahagiaan Abadi}

Setiap orang ingin mendapatkan kebahagiaan. Kebahagiaan yang ia harapkan bukanlah kebahagiaan yang sementara tetapi kebahagiaan abadi. Anehnya tidak setiap orang mendapatkan kebahagiaan abadi seperti yang ia harapkan.

\section{3) Memerhatikan Tubuh Kita Sendiri}

Apabila kita merenungkan dan memperhatikan tubuh kita sendiri sebagai manusia dengan kerangka dan susunan badan yang indah dan serasi dengan indra hati dan otak yang cerdas untuk menanggapi segala sesuatu di kanan kiri kita, akan sadar bahwa kita bukan ciptaan manusia, tetapi ciptaan Sang Maha Pencipta, Zat Yang Maha Ghaib dan Mahakuasa.

\section{4) Apabila Kita Mendapatkan Persoalan Yang Dilematis}

Dalam kehidupan sehari-hari orang sering dihadapkan pada persoalan yang sulit. Ia dihadapkan pada berbagai pilihan. Ia harus memeras otak, memperimbangkan untung-rugi, plus-minus, dan aspek-aspek lain yang akhirnya dapat menentukan keputusannya.

\section{5) Firman Allah SWT}

Disamping empat fenomena di atas Allah dengan tegas menyatakan dalamdalam Al-Quran bahwa sejak dalam kandungan manusia sudah memiliki agama. Allah SWT berfirman:

Artinya:Dan (ingatlah), ketika Tuhanmu mengeluarkan keturunan anakanak Adam dari sulbi mereka dan Allah mengambil kesaksian terhadap jiwa mereka (seraya berfirman): "Bukankah aku ini Tuhanmu?" mereka menjawab: "Betul (Engkau Tuban kami), Kami menjadi saksi". (kami lakukan yang demikian itu) agar di hari kiamat kamu tidak mengatakan: "Sesungguhnya Kami (Bani Adam) adalah orang-orang yang lengah terhadap ini (keesaan Tuhan)". 
Dari ayat di atas Allah mempersaksikan diri-Nya di hadapan jiwa-jiwa manusia dan jiwa-jiwa itu mengakui eksistensi-Nya. Jadi, sebelum manusia lahir ke muka bumi Allah telah membekali manusia dengan keyakinan akan adanya Tuhan (agama), sehingga ketika manusia akhirnya mengingkari fitrah kejadiannya ini, manusia akan menanggung resiko akibat kelalaiannya. Dengan demikian, jelaslah bahwa keberadaan manusia tidak dapat dipisahkan dengan agama.

\section{b. Gambaran Manusia Beragama (Ekspresi Religius)}

Gambaran pokok manusia beragama adalah penyerahan diri. Ia menyerahkan diri kepada sesuatu yang Maha Ghaib lagi Maha Agung. Ia tunduk lagi patuh dengan rasa hormat dan khidmat. Ia berdo'a, shalat, dan berpuasa sebagai hubungan vertikal (hablun minallah) dan ia juga berbuat segala sesuatu kebaikan untuk kepentingan sesama umat manusia (hablun minannas), karena ia percaya bahwa semua itu diperintahkan oleh Zat Yang Maha Ghaib serta Zat Yang Maha Pemurah. Penyerahan diri itu oleh manusia yang beragama tidak merasa dipaksa oleh sesuatu kekuatan yang ia tidak dapat mengalahkan.

Pengalaman manusia beragama dalam menjalankan aturan-atura agama mengintegrasikan hidupnya, sehingga hidupnya menjadi bertujuan dan bermakna. Tujuan itu terdapat dalam agama. Seringkali kita melihat orang yang berkecukupan, berilmu, berpangkat, dan berkuasa tetapi merasa bahwa hidupnya sepi, kosong, tidak ada kesatuan dan merasa adanya disintegrasi karena tidak adanya tujuan (lonely in the crowd).

\section{c. Kebutuhan Manusia akan Agama}

Kebutuhan manusia akan agama tidak dapat digantikan dengan kemampuan ilmu pengetahuan dan teknologi yang juga dapat memenuhi kebutuhan manusia dalam aspek material. Kebutuhan manusia akan materi tidak dapat menggantikan peran agama dalam kehidupan manusia. Masyarakat Barat yang telah mencapai kemajuan material ternyata masih belum mampu memenuhi kebutuhan spiritualnya.

Manusia dengan akalnya dapat melahirkan ilmu pengetahuan dan teknologi, tetapi akal saja tidak mampu menyelesaikan seluruh persoalan yang dihadapi manusia. Terkait dengan hal ini agama sangat berperan dalam mempertahankan manusia untuk tetap menjaganya sebagai manusia. Kebutuhan manusia terhadap agama mendorongnya untuk mencari agama yang sesuai dengan harapan-harapan rohaniahnya.

\section{Simpulan}

Itulah gambaran singkat mengenai pandangan Islam tentang manusia danbagaimana keterikatan manusia dengan agama. Tentu saja masih banyak hal yangbisa diungkap tentang keunikan manusia sebagai makhluk yang paling 
mulia dimuka bumi ini. Kemuliaan manusia terutama terletak pada kelengkapan fitrahnyadibandingkan makhluk yang lain. Dengan akalnya manusia dapat menaklukkandunia ini. Namun, kelebihan manusia ini tidak akan terus bertahan hingga dibawamenghadap ke hadiran Allah Swt. Ketika manusia tidak mampu menggunakan akalnya dengan baik dansemua perilakunya dikendalikan oleh nafsunya, maka manusia tidak lagi menjadimakhluk yang terbaik, akan tetapi justeru sebaliknya manusia akan menjadimakhluk yang paling hina. Disinilah manusia sangat membutuhkan agama yangdapat dijadikan sebagai kendali di dalam memanfaatkan bekal-bekal fitrahnya. Agama bisa mengarahkan manusia bagaimana seharusnya bersikap danberperilaku sehingga manusia akan tetap menjadi makhluk yang terbaik dankembali kepada Allah dalam keadaan Muslim (berserah diri kepada-Nya). Agamalah yang dapat menjamin manusia memiliki moral atau karakter muliasehingga manusia menjadi mulia di hadapan Allah dan di hadapan manusia sertamakhluk lainnya.

\section{Referensi:}

Aflatun Mukhtar, Tunduk kepada Allah: Fungsi dan Peran Agama dalam Kehidupan Manusia, Jakarta: Paramadina, 2001.

Anshary, Endang Saefuddin, Islam, Filsafat dan Agama, Surabaya: Bina Ilmu, 1979. Dadang Kahmad, Sosiologi Agama, Bandung: Remaja Rosdakarya, 2009.

Nasution, Harun, Islam Ditinjau dari Berbagai Aspeknya, Jakarta: UI Press. 1985.

Koentjaraningrat, Pengantar Antropologi, Jakarta: Rineka Cipta, 2002. 